\title{
Funkcja miejsc pracy w rozwoju i dobrobycie miast okresu globalizacji
}

\section{Function of places of employment in the development and the prosperity of cities in the period of the globalization}

\begin{abstract}
Streszczenie
Postęp w wytwórczości dóbr materialnych, a więc produktów przemysłowych i żywnościowych, przyniósł przesunięcia w podstawowych grupach zatrudnienia. Kraje wysoko rozwinięte usuwają ze swego terenu przemysł ciężki, surowcowy, energochłonny i uciążliwy dla środowiska. Rozwijają gospodarkę opartą na wiedzy, którą charakteryzują produkty o niskim nakładzie materiałowym, a wysokim wkładzie myśli technicznej i innowacyjności. Aktywizuje się tzw. sektor usług. To obecność tych aktywności i udział w międzynarodowym oraz krajowym podziale pracy decyduje o ekonomii, rozwoju miast i regionów oraz o zamożności jego mieszkańców. Wywiera też wpływ na zmieniający się wyraz przestrzenny miast.
\end{abstract}

Słowa kluczowe: industrializacja, urbanizacja, gospodarka oparta na wiedzy

Abstract

Progress in the production, that is industrial and food products brought is driving of heaving the employment in basic groups. The developed countries are removing the, raw material, energy intensive and troublesome heavy industry from their area for the environment. They are developing economy based on the knowledge of which products are characteristic about the low material, but big contribution of technical thinks and innovations. The so-called service sector is being developed. These are a presence of these activities and a participation in global and domestic dividing up of work is deciding on economics, of development of cities and regions and about wealth of his residents. He is also affecting the changing image on the changing image on the spatial expression of cities.

Keywords: industrialization, urbanization, the economy based on the knowledge 
Obecny etap rozwoju naszej cywilizacji jest różnie określany. W zależności od specjalności i punktu widzenia podkreśla się i uwypukla różne aspekty. To, co jest bezsporne, to przyśpieszenie rytmu przemian i obfitość zdarzeń, które można by sparafrazować porzekadłem-życzeniem: obyś żył w ciekawych czasach. Niewątpliwie obecne czasy są nader interesujące.

Z punktu widzenia architekta i urbanisty najciekawszy jest szybki rozrost struktur miejskich. Jak wykazuje, omawia proces i szkicuje koncepcje futurystyczne Elżbieta Węcławowicz-Bilska ${ }^{1}$, proces urbanizacji doprowadzi do sytuacji, w której około $75 \%$ populacji naszego globu mieszkać będzie w miastach. Stan ten spodziewany jest już w połowie tego wieku, ale w niektórych regionach i krajach jest już bliski osiągnięcia, jak przykładowo w Europie Zachodniej.

Miasta rozwijają się i rosną z wielu względów. Często podkreśla się ich atrakcyjność i synergiczne oddziaływanie na aktywność ludzką. Otóż miasta charakteryzują się dużym zagęszczeniem ludzi, co sprzyja większej ilości i różnorodności kontaktów między nimi. Przekłada się to na większą produktywność i kreatywność jednostek. I tak im większe miasto, tym większy dochód (w przeliczeniu na głowę) oraz większa liczba wynalazków i patentów² ${ }^{2}$ Jednocześnie większa koncentracja ludzi sprzyja intensywniejszemu wykorzystaniu infrastruktury, która rośnie wolniej niż liczba mieszkańców - im większe miasto, tym mniej w przeliczeniu na mieszkańca dróg, stacji benzynowych i instalacji energetycznych. Miasta są też centrami kultury i dokonań artystycznych. Profesor Andrzej Robowski z Ecole Speciale d’Architecture w Paryżu twierdził, że: „miasto jest najwspanialszym dziełem ludzkim, łączącym wszystkie dziedziny sztuki" ${ }^{3}$.

Historia miast jest długa i sięga początków neolitu, a więc początku przejścia z okresu nomadyzmu do osiadłego trybu życia i gospodarki. Prawzoru miast można się dopatrywać w założeniu Jerycha z okresu około 8 tysięcy lat przed Chrystusem. Najstarsze europejskie założenia urbanistyczne są późniejsze i za takie uważa się realizacje pochodzące z obszarów basenu Morza Egejskiego, z kultur: trojańskiej, minojskiej i mykeńskiej, z okresu lat 3 tysiące do 1 tysiąca przed Chrystusem.

Miasta powstawały jako odpowiedź na różne potrzeby gospodarcze i wojskowe jako osady służebne przy zamkach i rezydencjach władców, na skrzyżowaniach szlaków handlowych jako osady kupieckie i rzemieślnicze, z rozwinięć warownych obozów rzymskich, ale także jako wielkie skupiska - metropolie miasta-państwa ${ }^{4}$. Na ogół jednak, jak na obecną skalę urbanizacji, były to twory niewielkie. Wystarczy podać jako przykład Kraków, który jako miasto królewskie, stołeczne, w okresie Pierwszej Rzeczypospolitej, w szczytowym momencie rozwoju demograficznego (około roku 1530), liczył zaledwie 30 tysięcy mieszkańców 5 . Skokowy rozwój miast w Europie nastąpił dopiero w okresie przechodzenia ze struktur agrarnych (feudalnych) w przemysłowe, co wiązało się z rozwojem formacji demokratycznych i liberalnych w gospodarce.

Industrializacja spowodowała radykalne zmiany w organizacji i technologiach produkcji, w transporcie i w rozwoju nowych dziedzin gospodarki. Pierwsza na drogę industrializacji 
wstąpiła Wielka Brytania, jeszcze w XVIII stuleciu, przekształcając się z prowincjonalnego królestwa położonego na krańcach Europy, w potężne imperium, w którym, jak mówiono: nie zachodziło słońce. Dalej przemiany objęły Francję, kraje niemieckie i pozostałe kraje europejskie. Po Wojnie Secesyjnej na drogę szybkiej industrializacji wstąpiły Stany Zjednoczone Ameryki Północnej, rozbudowując ponadto transkontynentalną sieć kolejową, agencje handlowe, reklamowe, bankowe i ubezpieczeniowe, a także agencje i wydawnictwa prasowe.

Przejście z formacji agrarnych o stosunkach feudalnych do struktur industrialnych i demokracji kapitalistycznej nie odbyło się ewolucyjnie i pokojowo. Napięcia społeczne i polityczne obfitowały w spięcia, wojny domowe i rewolucje - w tym i dekapitacje królów, a więc pomazańców bożych, w Anglii i Francji. Zrodziły się nowe struktury polityczne, gospodarcze i nowe stosunki pracy, ale kraje które przeprowadziły tzw. rewolucję przemysłową szybko się rozwijały i rozrastały stając potęgami ekonomicznymi, militarnymi i kolonialnymi ${ }^{6}$.

Rozwój przemysłu przyniósł zasadnicze zmiany nie tylko w siłach wytwórczych, organizacji pracy, we wzroście produkcji żywności i dóbr konsumpcyjnych, a w konsekwencji we wzroście liczebnym społeczeństw, w ogólnym wzroście zamożności oraz w przekształceniach cywilizacyjnych i stylu życia, a także i w mentalności społeczeństw. Trudno byłoby wprost skrótowo wyliczyć, ile i jak dalece uprzemysłowienie przekształciło społeczności agrarne, ale szereg zmian wydaje się być do dziś nieodwracalnymi. Aspekty wolności i demokracji, w tym prawa człowieka i obywatela, wolność wyznania, wolności aktywności ekonomicznej i swobodnego przepływu kapitałów wydają się być już niezbywalnymi zdobyczami społeczeństw krajów wysoko rozwiniętych. Zmieniło się zasadniczo podejście do organizacji pracy - z kampanijnego, podyktowanego rytmami przyrody, do pracy potokowej i determinowanej potrzebami rynku. Radykalnej przebudowie uległo środowisko aktywności i pracy, a także stosunki wytwórcze. Do aspektów najbardziej zauważalnych należą przesunięcia w podstawowych grupach zatrudnienia, a więc przepływ siły roboczej z produkcji żywności do sektora wytwórczości materialnej - przemysłu. Tu skala była ogromna, a konsekwencją industrializacji stała się, rozwijana po dziś urbanizacja. To rozwój przemysłu i napływ ludności ze wsi do miast w poszukiwaniu pracy w powstających zakładach, spowodował gwałtowny rozrost miast i lokowanie nowych jednostek w rejonach rozwoju górnictwa, hutnictwa i tkalnictwa. W krajach Zachodniej Europy był to wiek XIX, na naszym terenie proces ten nastąpił ze znacznym opóźnieniem ${ }^{7}$. Spektakularnymi wyjątkami jest rozwój konurbacji Górnego Śląska, bazującego na wydobyciu węgla i hutnictwie, oraz rozwój dwóch ośrodków włókiennictwa - Łodzi i Białego Stoku. Zwłaszcza Łódź stała się symbolem miasta przemysłowego, powstałego praktycznie na surowym korzeniu, które rozkwitło w drugi pod względem wielkości ośrodek miejski na ziemiach polskich. Początek planowej industrializacji kraju nastąpił w okresie międzywojennym. Sporym nakładem starań i kosztów doprowadzono do scalenia w jeden organizm trzy odśrodkowo skomunikowane i powiązane gospodarczo tereny zaborów, w tym scalono układ sieci kolejowej, który na terenie zaboru rosyjskiego był szerokotorowy. Musiano od nowa wznieść przemysł zbrojeniowy, gdyż na terenie Polski w roku 
1918 nie było ani jednej fabryki broni i amunicji (sic!). W roku 1921 rozpoczęła się budowa portu i miasta Gdynia, polskiego okna na świat i jednego z najnowocześniejszych, wówczas na świecie założenia portowego. W roku 1936 rozpoczęto wznoszenie Centralnego Okręgu Przemysłowego, uważanego za największe przedsięwzięcie ekonomiczne II Rzeczypospolitej. Rozwinęły się wtedy na jego terenie takie miasta jak Rzeszów, Mielec i Świdnik i powstały nowe, jak Stalowa Wola ${ }^{8}$. Jednakże właściwy proces industrializacji nastąpił w Polsce po II wojnie światowej. Główny nacisk poszedł w stronę przemysłu ciężkiego, wydobywczego i energetyki, a także przemysłu stoczniowego, maszynowego i chemicznego, a w latach 70. i w stronę uprzemysłowionego budownictwa mieszkalnego. Rozbudowa przemysłu wpłynęła na rozwój sieci osadniczej. Powstały nowe ośrodki miejskie, jak przykładowo Nowe Tychy. Rozbudowano miasta istniejące, czasem tworząc całe nowe dzielnice, jak przykładowo Nową Hutę pod Krakowem. Polska wyraźnie przekształciła się w kraj uprzemysłowiony. Nic dziwnego, że rozwój i dobrobyt ludności widziano we wznoszeniu i rozbudowie zakładów przemysłowych. Nic też dziwnego, że władze miast i województw zabiegały o inwestycje przemysłowe. Jeśli dodać do tego, że tereny były własnością państwa, a więc nic w praktyce nie kosztowały, sieci transportowe i instalacje infrastrukturalne były budowane w całości przez państwo, a aspekty ochrony środowiska praktycznie nie były uwzględniane, obraz w pełni industrialny staje się kompletny.

Nie ulega wątpliwości, że szybki rozwój przemysłu, określany jako rewolucja przemysłowa, przyniósł skok cywilizacyjny - wzrost zamożności, eksplozję demograficzną, rozwój nauki, w tym i medycyny, rozbudowę miast, sieci transportowych, głównie kolejnictwa i wyraźny rozkwit handlu i żeglugi morskiej. Tak zwana epoka żelaza, węgla i pary nie była jednak wyśnionym eldorado. Był to okres wyniszczającej, żmudnej, często ponad możliwości fizyczne człowieka pracy. Pracowało się długo, w ciężkich warunkach. Pracowali mężczyźni, kobiety i nagminnie dzieci. Wypadkowość była ogromna, przy dużej śmiertelności. Zarobki robotników były niewysokie, a poziom ich życia niski. Można śmiało twierdzić, że dzisiejsza zamożność i dobrobyt krajów wysoko rozwiniętych były tworzone żmudną i wyniszczającą pracą wielu pokoleń. Dopiero w okresie po I wojnie światowej warunki pracy zaczęły być korzystniejsze, a prawo pracy i instytucje je nadzorujące wprowadzane ${ }^{9}$.

W ślad za industrializacją postępowała urbanizacja. Napływ ludności wiejskiej do miast w poszukiwaniu pracy (a więc za tzw. chlebem) stał się lawinowy. Miasta zaczęły szybko rosnąć. W architekturze okres ten przyniósł istotny impuls do przemiany stylowej. Zrodził się modernizm. Jego genezy można dopatrywać się w wielu aspektach, zarówno ideologicznych jak i stricte estetycznych, ale niezaprzeczalnym faktem jest, że oprócz nowych materiałów - stali, betonu i żelazobetonu, oprócz fascynacji produkcją przemysłową i jej metodami wytwórczymi, nowymi maszynami (samochody, statki parowe, aeroplany) oraz szeroko pojętą estetyką inżynierską, istotny był tu impuls potrzeb urbanizacyjnych ${ }^{10}$. Otóż dziewiętnastowieczne miasta nie były przygotowane na przyjęcie rzeszy ludności napływowej ze wsi. Problemem była ich liczba, ale przede wszystkim fakt, że były to osoby o niskich kwalifikacjach, 
wykonujące nieskomplikowane czynności w produkcji, a więc i niezamożne. Osoby te nie było z reguły stać na kupno lub wynajem przyzwoitych mieszkań w kamienicach czynszowych. Dosłownie „gnieździły się" w oficynach, na poddaszach i w suterenach. Wymownie ich sytuację, warunki życia i standard mieszkania opisała Maria Konopnicka w utworach: W piwnicznej izbie, Jaś nie doczekał i Dym. Ta sytuacja postawiła przed architektami nowe wyzwanie. Przez całe wieki architekci projektowali i budowali dla inwestorów zamożnych. Wznosili zamki i pałace, rezydencje i wille, ratusze i teatry, kościoły klasztory. Teraz po raz praktycznie pierwszy na tak znaczną skalę stanęli wobec problemu wzniesienia miast lub dużych dzielnic mieszkaniowych dla osób niezamożnych. To ruch młodych, gniewnych i nie należy tego ukrywać, raczej o poglądach lewicowych architektów zrodził nowy nurt w koncypowaniu architektury i miast. Zamiast ozdób i zdobień, zamiast wysokich, obszernych pomieszczeń, zamiast zwartej, kwartalnej zabudowy - proste i wysokie, z betonu i stali, położone w zieleni, z dostępem do światła i świeżego powietrza. Mieszkania małe, niewysokie i proste, bo dla osób niezamożnych. Ale za to wyposażone w instalacje i udogodnienia sanitarne. W roku 1922 Le Corbusier projektuje Une Ville Contemporaine de trois millions d'habitants - miasto współczesne dla trzech milionów mieszkańców. Takiego miasta jeszcze dotąd nie było - takiej idei, takiej formy zamieszkania i takiej skali. Nad nowym miastem unosi się symbol nowoczesności - maszyna latająca, a przez miasto prowadzi szeroka droga pełna innych symbolów nowoczesności - jeżdżących maszyn, czyli samochodów (il. 1 i 2 ) $^{11}$. Nic dziwnego, że domy miały być funkcjonalistycznymi maszynami do mieszkania ${ }^{12}$.

Polska, co warto przypominać, też miała swój wkład w rozwój myśli modernistycznej urbanistyki. Powszechnie zauważona została Warszawa Funkcjonalna z roku 1934, autorstwa Jana Chmielewskiego i Szymona Syrkusa. Projekt zyskał uznanie i w celu szerokiego rozpowszechnienia opublikowano go w językach: niemieckim, francuskim, angielskim i hiszpańskim i został przez CIAM przyjęty jako wzorcowe, modelowe rozwiązanie dla nowoczesnego miasta ${ }^{13}$.

Okres industrialny w krajach wysoko rozwiniętych zaczął z czasem przechodzić w dobę postindustrialną. Tu wskaźnikiem jest procentowy udział zatrudnionych. Spadek ilości zatrudnionych w produkcji przemysłowej, powodowany rozwojem technologicznym i informatycznym, oznacza wchodzenie danego kraju w tzw. okres poprzemysłowy ${ }^{14}$. W Stanach Zjednoczonych początek takich przemian odnotowano w pierwszej połowie lat 60., gdy zatrudnienie w przemyśle zaczęło się obniżać, a wzrastać w tzw. sektorze usług. Sektor ten obejmuje wiele aktywności i działów gospodarki, w tym głównie: usługi właściwe, gastronomię, handel, rzemiosło, transport i komunikację, tworzenie, przetwarzanie, dystrybucję i komercjalizację informacji, szkolnictwo, naukę i badania naukowe, obronę i bezpieczeństwo, sektor bankowy i asekuracyjny, a także prasę i media, turystykę, rozrywkę, sport i rekreację (il. 3). Dalej, z pewnym opóźnieniem w stosunku do Ameryki, zjawisko rozbudowy sektora tzw. usług zaczęło występować i w innych wysoko rozwiniętych krajach w Europie Zachodniej ${ }^{15}$. Ta faza rozwoju gospodarczego była możliwa dzięki postępowi w mechanizacji 
czynności i procesów wytwórczych, dalej ich automatyzacji i w końcu robotyzacji. Ten postęp objął nie tylko produkcję przemysłową, ale i produkcję roślinną, zwierzęcą, sadownictwo i gospodarkę leśną. Również w szerokim sektorze usług informatyzacja i cyfryzacja stały się podstawą działania. Te przeobrażenia są efektem wkładu burzliwie rozwijającej się techniki i technologii, co jest możliwe dzięki intensyfikacjom badań zarówno podstawowych, jak i wdrożeniowych na potrzeby wytwórczości. Łączy się z rozwojem nauki i szkolnictwa wyższego, a także z nasilającą się tendencją do sprzężenia postępu wiedzy i umiejętności z wdrożeniami na rzecz gospodarki. W konsekwencji powstało pojęcie gospodarki opartej na wiedzy, a więc gospodarki której produkty cechuje mały udział materiałów a wysoki wkład myśli inżynierskiej i innowacyjności. Równocześnie kraje wysoko rozwinięte dążą do usunięcia ze swoich terenów przemysłu ciężkiego, energochłonnego, szkodliwego ekologicznie, rozwijając przemysły wysoko zaawansowanych technologii.

Rozwój zaawansowanych technik i technologii w sposób oczywisty wymaga doskonałych kadr, zarówno badawczych jak i wdrożeniowo-produkcyjnych. Idąc w tym duchu i chcąc sprostać konkurencji gospodarki amerykańskiej i rosnących w siłę gospodarek azjatyckich, w tym w pierwszym rzędzie chińskiej, indyjskiej i indonezyjskiej, Unia Europejska przyjęła w roku 2000 Strategię Lizbońską. Jednym z jej celów jest uzyskanie skolaryzacji na poziomie wyższym w zakresie $30 \%$ do $40 \%$ populacji. Jest to oczywiście poważne wyzwanie, a jak wykazuje praktyka, nie tak łatwe do osiągnięcia i o znacznych obciążeniach finansowych. Z drugiej strony, rozbudowywana nauka i szkolnictwo wyższe stały się istotnym elementem miastotwórczym, funkcją obecną w każdym większym ośrodku, odgrywającą istotną rolę nie tylko w życiu kulturalnym, w obrazie miasta, ale i w jego ekonomii i gospodarce ${ }^{16}$.

Taka nowa sytuacja gospodarczo-społeczna przyniosła znaczne przewartościowania w obrazie aktywności zawodowej. Dotyczy to zarówno poziomu wykształcenia, jak i warunków pracy - wyposażenia maszynowego i obciążenia pracowników, z coraz mniejszym udziałem obciążeń fizycznych i wzrostem obciążeń mentalnych. Zmienił się też zasadniczo, w krajach wysoko rozwiniętych, kontekst kulturowy aktywności zawodowej ${ }^{17}$.

Postęp cywilizacyjny krajów wysoko rozwiniętych, będący obecnie w fazie przejścia do struktur poprzemysłowych, znajduje swój wyraz w niespotykanym jak dotąd w historii wzroście zamożności. Oczywiście, jak mówi przewrotne porzekadło: socjalizm to było społecznie sprawiedliwe dzielenie biedy, a kapitalizm jest niesprawiedliwym, dzieleniem bogactwa - różnice w zamożności poszczególnych grup społecznych, zawodowych i w poszczególnych regionach są ogromne. Jednakże przeciętny poziom zamożności i zaspokojenia potrzeb jest jak nigdy dotąd wysoki. Nigdy dotąd warunki życia nie były tak dobre, a dostęp do wygód i komfortu tak powszechny. Nigdy dotąd ceny żywności, w stosunku do zarobków nie były tak niskie, nigdy dotąd nie było takiej profuzji środków konsumpcyjnych, usług i możliwości realizacji potrzeb i aspiracji. Nigdy dotąd turystyka, sport i rekreacja nie były tak rozwinięte i tak powszechnie dostępne. Nigdy dotąd ludzie tak masowo nie podróżowali, zwiedzali i poznawali. Nigdy dotąd możliwości porozumiewania i komunikacji nie były tak powszechne. 
Czasem spotyka się narzekania i utyskiwania oraz demagogiczne krytyki o rodowodzie ideologiczno-politycznym, ale wymowa faktów jest jednoznaczna. Jedynym w pełni obiektywnym i zasadniczym wskaźnikiem jest przeciętna długość życia. Oczywiście, od wartości statystycznej, zgodnie z wykresem krzywej Gaussa, są i znaczne odstępstwa, ale przeciętna oddaje obiektywnie tendencję. Dotyczy to wszystkich rozwiniętych państw, w tym i Polski. U nas jest to szczególnie łatwe do wykazania, gdyż przemiany ustrojowe po roku 1989 przyniosły wyraźne przyśpieszenie w postępie cywilizacyjnym. Obraz zmian demograficznych, na podstawie danych GUS, omawia Katarzyna Lis ${ }^{18}$. Otóż w roku 1950 mężczyźni średnio dożywali u nas do 56. roku życia, a kobiety do 62. W roku 2010, Polacy średnio żyli do roku 73., a Polki do roku 82. Ponieważ mieszkańcy najwyżej rozwiniętych krajów w Unii Europejskiej żyją jeszcze dłużej od nas o parę lat, można domniemywać, że wraz z dalszym rozwojem i zmniejszaniem dystansu do nich, tendencja wydłużania przeciętnego czasu trwania życia będzie się u na utrzymywać ${ }^{19}$.

Postęp w technice jest na ogół przyjmowany z powszechnym entuzjazmem, zwłaszcza wśród osób młodych, z radością korzystających z coraz nowszych osiągnięć i możliwości stwarzanych przez technikę, a także otwarć, dostępności i profuzji wyborów oferowanych przez wszechobecną globalizację. To już nie tylko proste zaspakajanie potrzeb konsumpcyjnych, ale i coraz wyraźniejsze aspekty hedonistyczne zaczynają nadawać ton rozwiązaniom, także architektonicznym. Również poszczególne kraje i regiony starają się usilnie o intensyfikację rozwoju, widząc w tym pomyślną przyszłość swoich społeczności ${ }^{20}$. Nic zatem dziwnego, że rzeczywistość potwierdza wywody Edwina Tytyka, wykazującego w swoich książkach, że współczesna technika należy do największych osiągnięć intelektualnych człowieka ${ }^{21}$. To nie tylko literatura, sztuka i nauka są świadectwami poziomu kultury i rozwoju intelektualnego, ale i wszechobecna w życiu, twórczości i szerzej, wszystkich aspektach aktywności człowieka technika, staje się immanentną składową i wyznacznikiem poziomu naszej cywilizacji. Obecnie, zwłaszcza w krajach wysoko rozwiniętych, trudno sobie już wprost wyobrazić sytuację bez łączności i wymiany informacji, bez możliwości transportu i komunikacji w skali globalnej, a także bez dostępu do produktów i usług ogólnoświatowych ${ }^{22}$.

Nie wolno jednakże zapominać, że każda rewolucja realizując swoje, przeważnie szczytne cele, niesie ze sobą i poważne zagrożenia. Przejście z formacji agrarnych, określanych częściej jako feudalne, do przemysłowych i demokratycznych, określnych jako kapitalistyczne, odbywało się w sposób burzliwy i obfitujący w spięcia, rewolucje i wojny. Analogicznie, przejście do okresu postindustrialnego, do gospodarki opartej na wiedzy i do globalnych struktur ekonomicznych nie może się obyć bez napięć i konfliktów, zarówno na płaszczyźnie światopoglądowej, ideologicznej, jak i polityczno-ekonomicznejej. Przyszłość jest oczywiście nieznana, a na razie możemy tylko stwierdzić, że szybkość zmian i ich rytm przyśpiesza i że żyjemy w okresie gwałtownych przewartościowań cywilizacyjnych ${ }^{24}$.

Myśląc o rozwoju miast, przy obecnym tempie i nieprzewidywalności przemian oraz wielości koncepcji i wizji rozwojowych, możemy jedynie oprzeć się pewnie na dotychczasowym 
kierunku ewolucji i na śledzeniu sytuacji w krajach wyprzedzających nas w rozwoju. Jak bowiem uczy doświadczenie, przesunięcia w czasie dają najpewniejsze przewidywania przyszłości. Patrzymy więc na kraje które nas wyprzedzają, za którymi podążamy i widzimy rzeczy, które będą się dziać i u nas w przyszłości. Trzy aspekty wydają się być tu wiodące, a to:

- Przesunięcia w podstawowych grupach zatrudnienia i rozwój struktur wiodących aktywności. W krajach nas wyprzedzających w rozwoju sektor tercjarny szybko się rozbudowuje. W jego ramach wiodąca staje się grupa osób zajmujących się tworzeniem, przetwarzaniem dystrybucją i komercjalizacją informacji, co w sposób już historyczny, wobec braku lepszego terminu, określa się mianem biur. W różnych krajach odsetek osób w nich pracujący jest różny, w zależności od tego jakie miejsce w międzynarodowym podziale pracy globalnego rynku zajmuje dany kraj i dany region. Ogólnie w Europie Zachodniej szacuje się go na od 25\% do $34 \%$ aktywnych zawodowo. Efektem jest szeroki ruch wznoszenia budynków, zespołów i dzielnic biurowych który w krajach Europy Zachodniej rozwinął się po okresie powojennej odbudowy jeszcze w latach 60 . Obecnie w dużych ośrodkach zespoły biur są funkcjonalnie i przestrzennie wyraźnymi dominantami w układach urbanistycznych. Największym w tym względzie ośrodkiem w Europie jest aktualnie Paryż z zasobami szacowanymi na ponad 53 miliony $\mathrm{m}^{2}$ powierzchni biurowej, nieznacznie wyprzedając $w$ tym względzie Londyn. Dla porównania zasoby biurowe Warszawy określa się na 5,1 miliona $\mathrm{m}^{2}$, a Krakowa (największego ośrodka regionalnego) na 0,85 miliona $\mathrm{m}^{2}$. Dla porównania, Oslo, liczące o 100 tys. mieszkańców mniej od Krakowa, ma zasoby szacowane na 8,5 miliona $\mathrm{m}^{2}$, a więc dziesięciokrotnie większe (sic!). Daje to obraz różnicy w rozwoju, w dostosowaniu do kierunku przemian i oczywiście w zamożności ${ }^{25}$.

Drugą funkcją intensywnie rozwijaną w ośrodkach miejskich krajów wysoko rozwiniętych jest sektor nauki, badań, laboratoriów i ośrodków wdrożeniowych oraz szkolnictwa wyższego. Jest to zaplecze bez którego gospodarka oparta na wiedzy nie mogłaby się rozwijać. Jest to też źródło napływu sporych środków i dobrych poborów wysoko kwalifikowanej kadry, a w konsekwencji zamożności ośrodka. Każde miasto, pragnące rozwijać się i uczestniczyć w krajowym, a szerzej międzynarodowym podziale pracy stara się mieć na swoim terenie szkoły wyższe i rozbudowywać sektor badań i wdrożeń.

Jest rzeczą oczywistą, zauważalną, a nawet rzucającą się w oczy, że te przemiany mają swoje odbicie w wielu aspektach. Najistotniejsze to aspekt społeczny i ekonomiczny, a dla architektów przestrzenny i wyraz estetyczno-wrażeniowy zmieniających się miast. Jest to wyraźny przyrost znacznych kubatur obiektów, swoiście lokalizowanych, zmieniających układ i wprowadzających nowy wyraz. To także rozwój funkcji im towarzyszących i przebudowa układów sieci transportowych komunikacji masowej i indywidualnej (il. 5 i 6).

- Rozwój sieci komunikacji w obsłudze kołowej (autostrady, drogi ekspresowe), kolejowej (szybkie pociągi łączące z siecią metropolii) i lotniczej wydaje się obecnie koniecznością, warunkującą większe i znaczniejsze gospodarczo inwestycje ${ }^{26}$. 
- Aspekt inteligencji i ekologii miast wydają się być przybierającymi na sile. Rozwój przestrzenny miast, wzrastający odsetek obywateli w nich i w ich aglomeracjach mieszkających, powodują, że zieleń jest uważana za coraz cenniejszy oraz stanowiący o statusie i demonstracji ekologiczności element. To już nie tylko parki, skwery i zieleńce, ale i ogrody wertykalne, zielone dachy i zielona tarasy, realizowane głównie w zwartej, gęstej zabudowie stają się istotnym elementem wyrazu miasta. Co więcej, dość szybko rozwija się idea tzw. farm pionowych, a więc produkcji żywności, zarówno roślinnej jak i zwierzęcej w miastach. To nowe ujęcie funkcjonalne i technologiczne dla idei miasta. Jeszcze nie wiadomo, jak dalece się powiedzie i rozwinie, ale znamienne jest, że analogicznie jak z produkcją odnawialnej energii, przodujące są tu kraje wysoko rozwinięte, mogące sprostać technicznie i finansowo w realizacji takiej produkcji.

Idea miasta inteligentnego (smart city), a więc całościowego i kompleksowego zarzadzania zarówno nieruchomościami miasta jak i bieżącą aktywnością jego obywateli, powstała w drugiej połowie XX wieku, a pierwsze elementy wdrożeń mają już ponad 30 lat. Koncepcja ta rozwija się i szybko ewoluuje, a także szeroko wdrażane są już jego niektóre elementy. Nic dziwnego, że jest to jedna z najbardziej obiecujących koncepcji działania miasta i lokalnej gospodarki w krajach rozwiniętych, zorientowana na wygodę i komfort mieszkańców, na maksymalizację wykorzystania zasobów i ekologiczne rozwiązania ${ }^{27}$.

Jest rzeczą oczywistą, że zmiany i tendencje do ich wprowadzania najbardziej są widoczne w dużych centrach aktywności gospodarczej, określanych czasem jako globalne metropolie. Tu są śledzone, tu wartości wskaźnikowe są najwyższe. Tu też podążanie za trendami daje najlepsze wyniki ekonomiczne, a więc liczne nowoczesne inwestycje, niskie bezrobocie i wzrost zamożności mieszkańców. My jeszcze jesteśmy daleko za krajami przodującymi w rozwoju, ale i u nas tendencje przemian rysują się jednoznacznie. W wyrywkowych przykładach, aktualna sytuacja przedstawia się następująco:

- Polska

- 38433 tys. mieszkańców

- średnia płaca -4350 zł brutto

- bezrobocie $-7,7 \%$

- Warszawa - stolica i największe miasto kraju oraz największy zasób powierzchni biurowej:

- 1754 tys. mieszkańców miasta i 2666 tys. mieszkańców aglomeracji

- średnia płaca - 5600 zł brutto

- stopa bezrobocia - $2,8 \%$

- Kraków - drugie pod względem wielkości miasto w kraju, największy regionalny ośrodek biurowy: 
- 765 tys. mieszkańców miasta i 1402 tys. mieszkańców aglomeracji

- średnia płaca -4500 zł brutto

- stopa bezrobocia - $3,6 \%$

- Olsztyn - miasto wojewódzkie w tzw. Polsce B:

- 173 tys. mieszkańców miasta i 222 tys. mieszkańców aglomeracji

- średnia płaca - 3600 zł brutto

- stopa bezrobocia - 14,9\%

Jest rzeczą oczywistą, że powyższe dane, zaczerpnięte z ogólnie dostępnych, powszechnie publikowanych badań GUS, są i wyrywkowe i nie dające pełnego obrazu, wyniku wielowątkowych uwarunkowań rozwojowych. Jednakże ich wymowa jest jednoznaczna. To ilość nowoczesnych miejsc pracy, wymagających wykształcenia i wysokopłatnych z zakresu aktywności sektora trzeciego i udział w międzynarodowym i krajowym podziale pracy decyduje o ekonomii, rozwoju miast oraz o zamożności jego mieszkańców.

Wszelkie zmiany w poszczególnych miastach dzieją się na tle regionów, te na tle krajów i stref gospodarczych. Całość zaś jest fragmentem międzynarodowego, globalnego rynku podziału pracy, zaangażowania ekonomicznego i stref wpływów otwartych przepływów ludzi, technologii i kapitałów. Mówiąc o rozwoju i dobrobycie w poszczególnych jednostkach, należy konstruując strategię zadawać sobie sprawę z miejsca, z zasobów i potencjałów, ale też z kierunków ewolucji, a więc z tego co posiadamy, czym dysponujemy, ale i dokąd zmierzamy. 


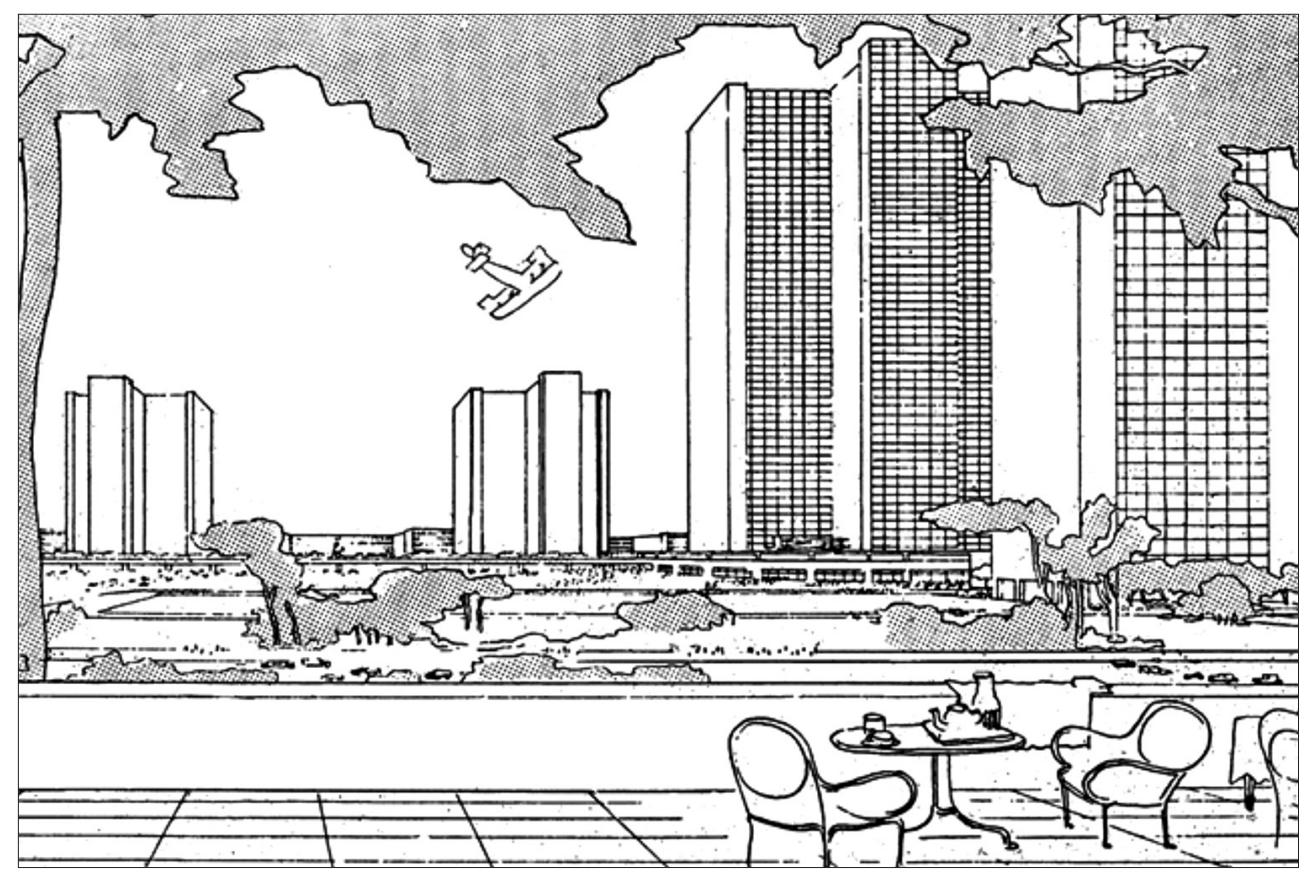

II. 1. Une Ville Contemporaine de trois millions d'habitants - miasto współczesne dla trzech milionów mieszkańców według projektu Le Corbusiera z roku 1922. Nad miastem unosi się jeden z symboli nowoczesności - aeroplan (źródło: Le Corbusier, P. Jeanneret, Oeuvre complete 1910-1929, Les Editions d'Architecture - Edition Girsberger, Zurich 1964, s. 37)

III. 1. Une Ville Contemporaine de trois millions d'habitants - contemporary city for three million residents according to the project of Le Corbusier from 1922. Above the city one of symbols of the modernity is rising - aeroplane 


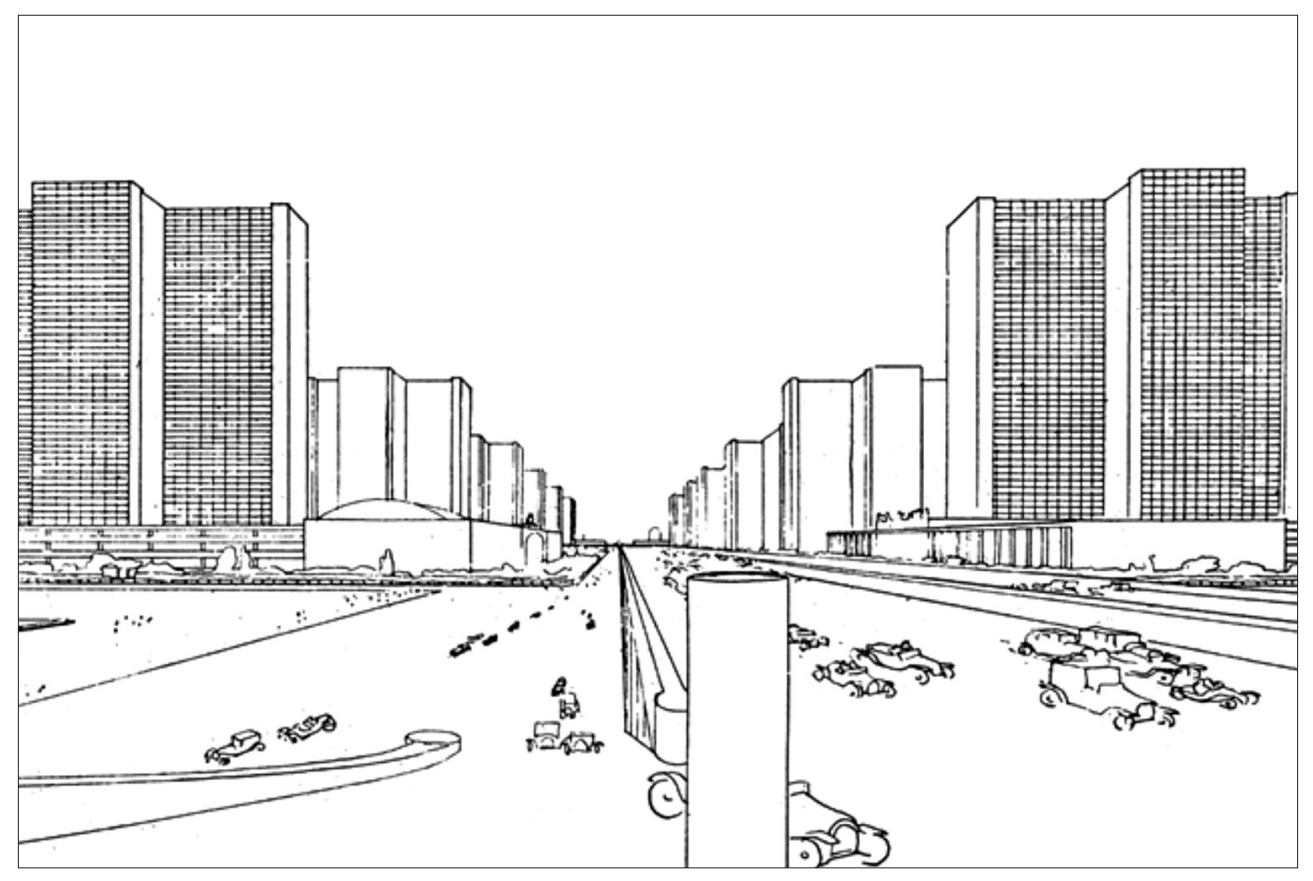

II. 2. Une Ville Contemporaine de trois millions d'habitants - miasto współczesne dla trzech milionów mieszkańców według projektu Le Corbusiera z roku 1922. Teraz już wiemy, że przez środek miasta nie należy prowadzić autostrady pełnej samochodów, ale wtedy wydawało się to symbolem nowoczesności (źródło: Le Corbusier, P. Jeanneret, Oeuvre complete 1910-1929, Les Editions d'Architecture - Edition Girsberger, Zurich 1964, s. 36)

III. 2. Une Ville Contemporaine de trois millions d'habitants - contemporary city for three million residents according to the project of Le Corbusier from 1922. Now we already know that through the midtown one should not lead a motorway full of cars, but then it seemed with symbol of the modernity 


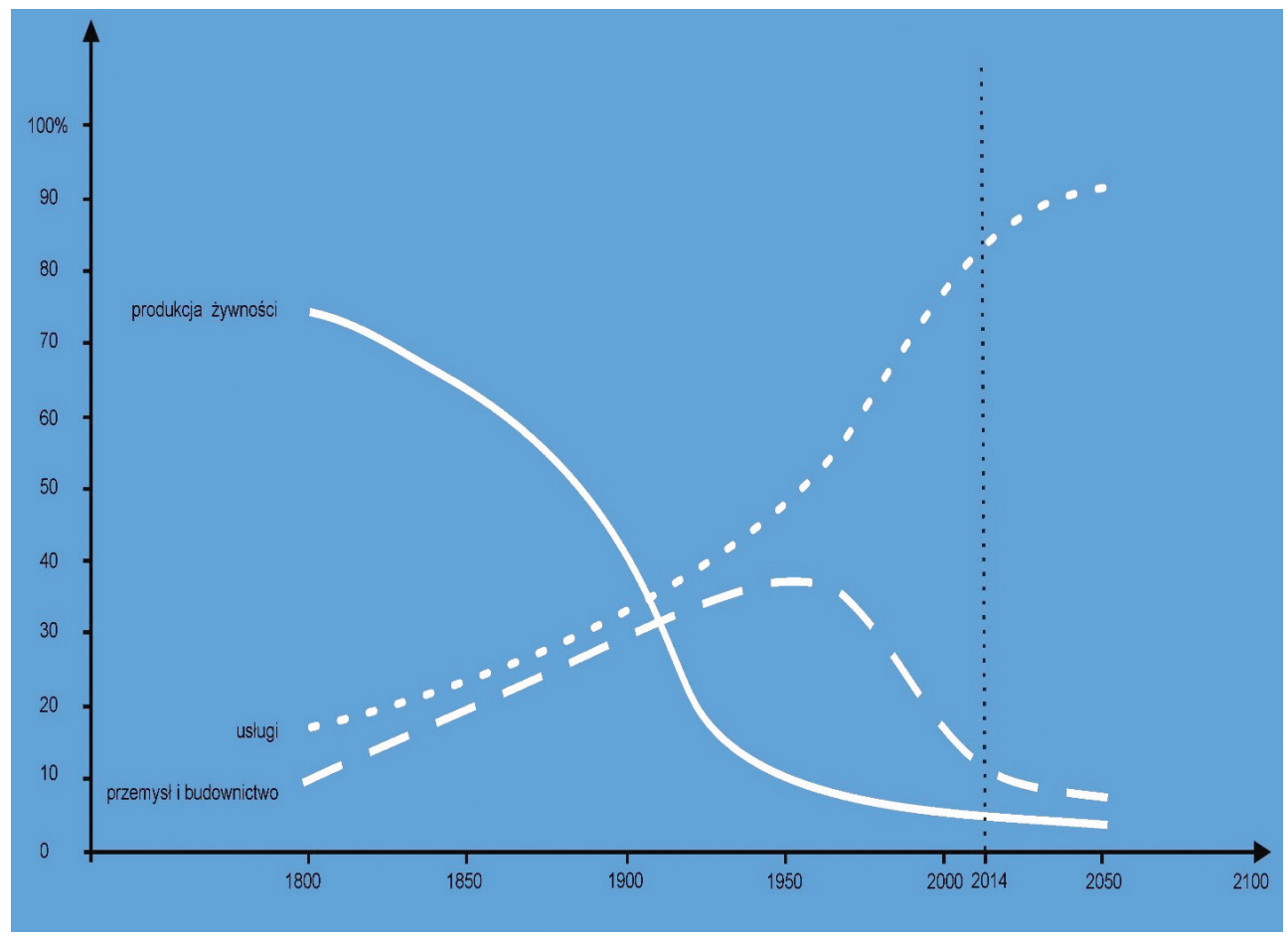

II. 3. Przesunięcia w podstawowych grupach zatrudnienia w USA, w ujęciu procentowym aktywnych zawodowo - opracowanie Katarzyna Zawada-Pęgiel na podstawie danych i publikacji KAMPR IPA III. 3. Of moving in basic professionally active groups of the employment in the USA, in the percentage presentation - study Katarzyna Zawada-Pęgiel on the basis of data and the publication of KAMPR IPA 


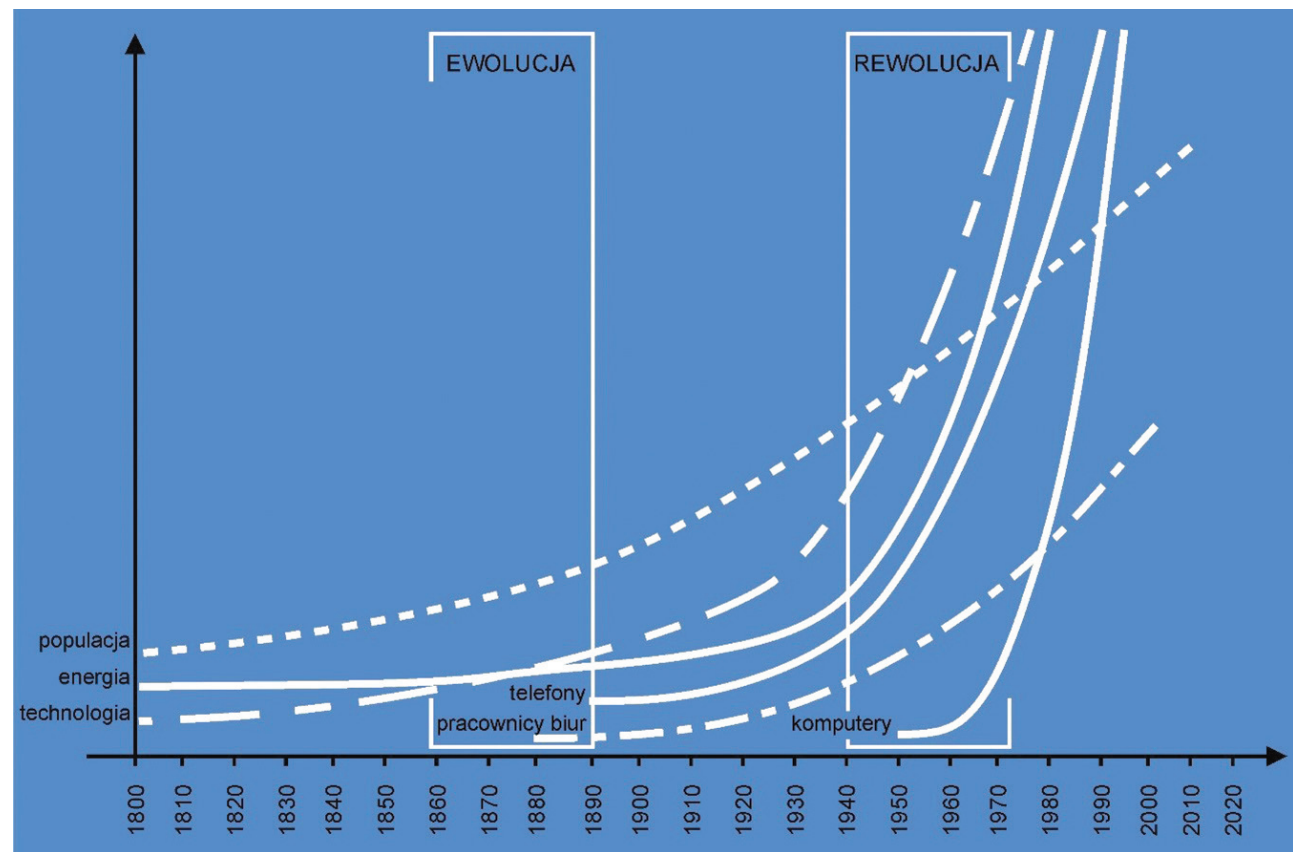

II. 4. Obrazowe ujęcie etapu ewolucji i rewolucji w rozwoju cywilizacji zachodniej - opracowanie Katarzyna Zawada-Pęgiel na podstawie badań Roberta Propsta (źródło: R. Propst, Le bureau évolutifun nouveau concept, Reboul \& Fils, Paris 1971, s. 12)

III. 4. The evolution and the revolution period in the development of the Western civilization - study Katarzyna Zawada-Pęgiel on the basis of studies of Robert Propst 


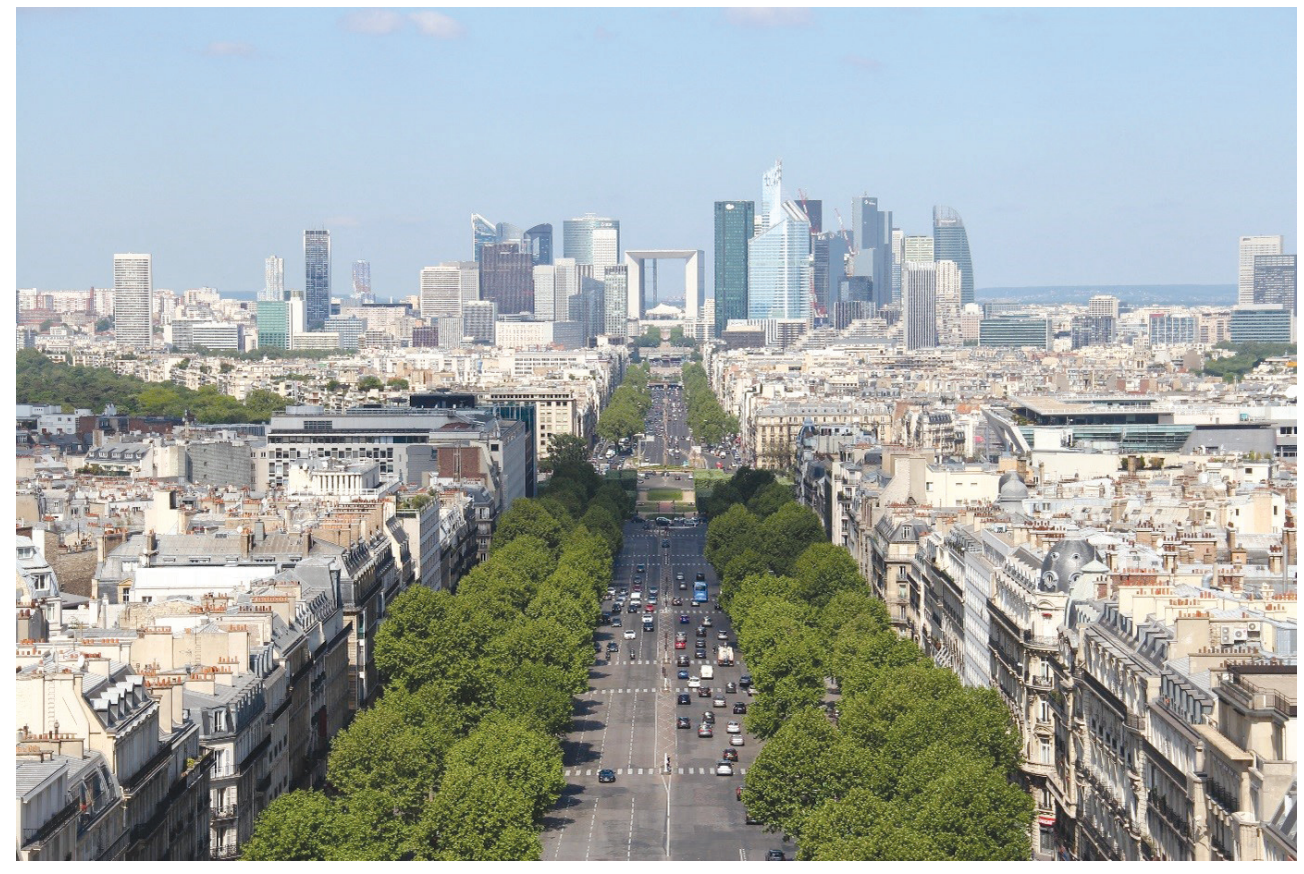

II. 5. Biurowe wieżowce dzielnicy La Défense, widziane z Łuku Triumfalnego w Paryżu - stan z czerwca roku 2012 (fot. Maciej Złowodzki)

III. 5. The offices tower of the district La Défense, seen from the triumphal arch in Paris - state from the June of the year 2012 


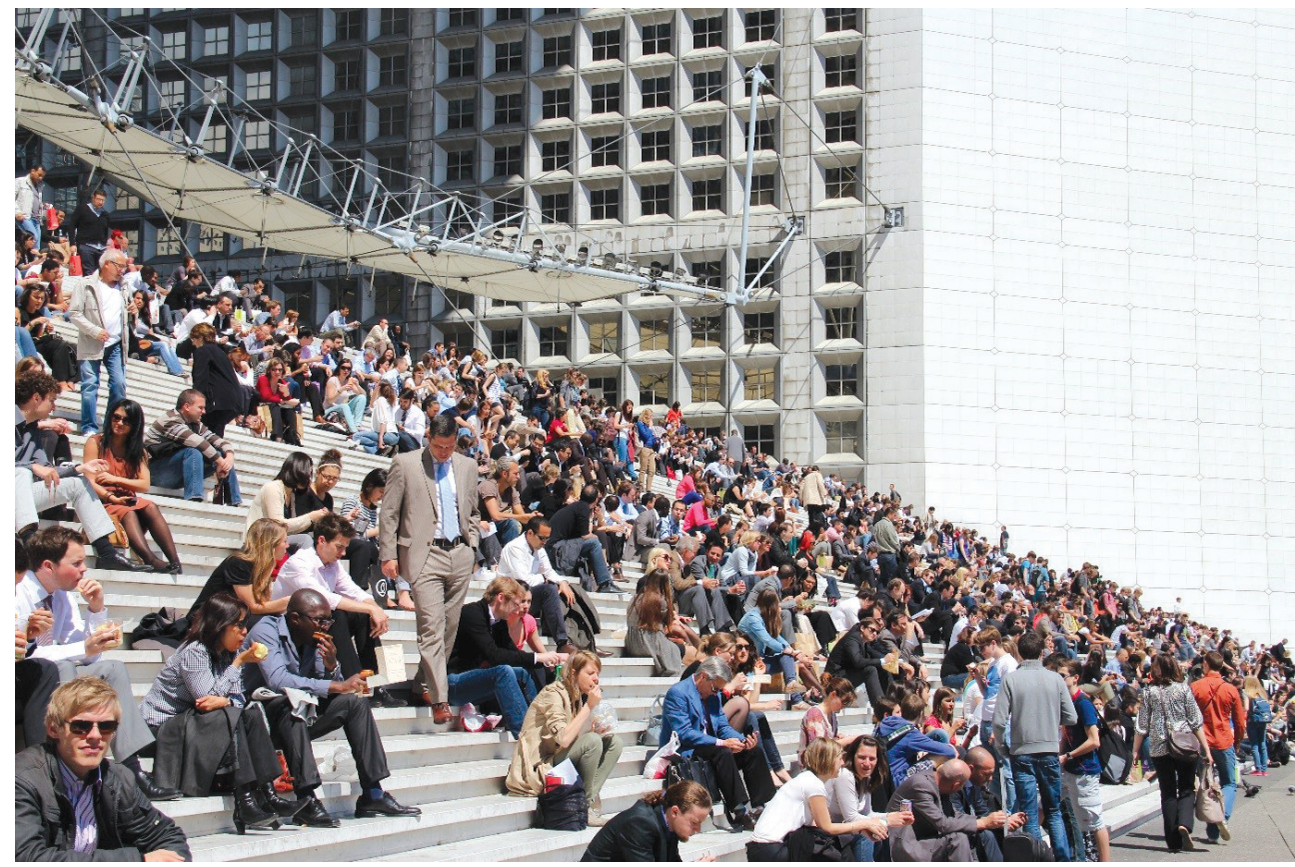

II. 6. Przerwa na południowy posiłek, w słoneczny dzień, w podparyskiej dzielnicy La Défense, w której pracuje przeszło 65 tysięcy pracowników biur - stan z czerwca roku 2012 (fot. Maciej Złowodzki) III. 6. Break to the noon meal, into a sunny day, in the district La Défense, in which is working over 65 thousand employees of offices - state from the June of 2012 


\section{PRZYPISY}

1 E. Węcławowicz-Bilska, Miasta i zurbanizowane struktury przestrzenne przyszłości, [w:] Ergonomia wobec wyzwań nowych technik i technologii, M. Złowodzki, T. Juliszewski, H. Ogińska, A. Taczalska (red.), Politechnika Krakowska, Kraków 2016, s. 123-138.

2 Każde zjawisko ma też i swoją tzw. drugą stronę medalu. W miastach, zwłaszcza dużych większa jest przestępczość i większa ilość zachorowań na wiele chorób zakaźnych, w tym i na AIDS.

3 Porównaj omówienie twórczości, prac i poglądów profesora Andrzeja Robowskiego, [w:] M. Złowodzki, Andrzej Robowski - filozofia architekta i dydaktyka, Czasopismo Techniczne, 2-A/1995, s. 81-100.

4 Wystarczy przypomnieć, że ludność Rzymu, w szczytowym okresie rozwoju imperium romanum (liczącego blisko 56 milionów mieszkańców w drugiej połowie 2wieku po Chrystusie), szacowana jest na około 1 milion.

5 Porównaj omówienie rozwoju Krakowa w opracowaniu Jacka Purchli: Jak powstał nowoczesny Kraków (Wydawnictwo Literackie, Kraków 1979).

6 Spektakularny w tym względzie jest przykład Japonii, która z feudalnego w naszych kategoriach średniowiecznego państwa przekształciła się w nowoczesną potęgę, dzięki tzw. rewolucji Meiji. W roku 1868 rozpoczął się proces, centralnie wprowadzanych, zasadniczych zmian i modernizacji na wzór zachodni. Głównymi celami było zlikwidowanie feudalizmu, centralizacja władzy wokół cesarza (likwidacja siogunatu) i przeprowadzenie reform, kończących zacofanie Japonii wobec krajów przodujących w rozwoju, głównie Wielkiej Brytanii i USA. Centralnym organem rządowym stała się Wielka Rada Stanu, sprawująca kontrolę nad instytucjami ustawodawczymi, wykonawczymi i sądowniczymi. Po wielu zmianach jej struktury, w roku 1885 powstał nowoczesny system rządów gabinetowych, wzorowany na państwach zachodnich. Zmieniono też stolicę. W 1869 roku cesarz przeprowadził się z Kioto do Edo, które przemianowano na Tokio. W roku 1871 zmieniono podział administracyjny kraju, wprowadzając prefektury i miasta wydzielone. W 1873 r. zreformowano system finansowy i przeprowadzono reformę podatków od ziemi. Zmieniono strukturę gospodarki, przekształcając Japonię ze słabego kraju rolniczego w szybko rozwijający się kraj przemysłowy (przemysł maszynowy, stoczniowy, włókienniczy). Stworzono również ogólnonarodową, nowoczesną armię z poboru. Wprowadzono kalendarz gregoriański i cofnięto wszystkie antycudzoziemskie zarządzenia. Rząd dążył do unowocześnienia kraju i dostosowania obcych kulturowo wzorów do japońskich realiów i tradycji. Dzięki temu zlikwidowano zacofanie, a zarazem zachowano narodową tożsamość. W 1889 r. promulgowano Konstytucję Wielkiego Cesarstwa Japonii, która formalnie przekształciła kraj w nowoczesną monarchię konstytucyjną. Zmiana systemu politycznego i społecznego doprowadziła do napięć społecznych. Doszło do wystąpień zbrojnych, tłumionych przez armię rządową. Najpoważniejsze były bunty kasty samurajów. W roku 1871 zniesiono 
wszystkie tytuły samurajskie i warstwa samurajska została formalnie zlikwidowana. Ostateczne rozwiązanie nastąpiło w krwawej rozprawie we wrześniu 1877 roku, kończącej tzw. Rebelię Satsumy, podczas której zginęło blisko 20 tysięcy wojowników wraz ze swoim przywódcą Saigo Takanarą. Przeprowadzone reformy szybko uczyniły z Japonii naprzód mocarstwo regionalne na Dalekim Wschodzie, czego z zaskoczeniem przykro doświadczyli Rosjanie rozgromieni na morzu i na lądzie w wojnie z lat 1904-1905, a następnie potęgę gospodarczą i wojskową na skalę światową i o aspiracjach imperialnych, czego wyrazem stał się jej udział w II wojnie światowej.

7 Radko się o tym mówi i pisze, ale pierwsze działania planowe i realizacyjne w zakresie rozwoju przemysłu podjęto na ziemiach polskich w okresie Królestwa Kongresowego. Wzniesione wówczas zakłady zostały celowo splądrowane, zniszczone i spalone przez wojska rosyjskie jako jedna z wielu represji po Powstaniu Listopadowym w roku 1831.

8 Mimo spektakularnych sukcesów i wysiłku włożonego w industrializację kraju, należy z naciskiem stwierdzić, że II Rzeczypospolita była krajem biednym, rolniczym i zacofanym gospodarczo, który dopiero wstępował na drogę unowocześnienia. Wystarczy podać, że produkcja żelaza wynosiła w roku 1938 zaledwie 2,5 miliona ton. Dla porównania, w PRL, w szczytowym okresie, sama Huta Lenina pod Krakowem produkowała około 6,5 miliona ton surówki. Jak dalece byliśmy odlegli od europejskich krajów rozwiniętych, dotkliwie uzmysłowiła społeczeństwu zbrojna konfrontacja z Rzeszą Niemiecką we wrześniu 1939 roku.

9 Wystarczy podać, że w Europie ośmiogodzinny dzień pracy stał się powszechną regułą dopiero po roku 1918. Pierwszy wprowadził go Lenin w Rosji, w ramach rewolucji bolszewickiej. Z chwilą gdy komuniści zrealizowali tę, obecnie powszechną regulację, na zasadzie konkurencyjnej rywalizacji wprowadziły ją i kraje kapitalistyczne.

10 Zafascynowanie techniką oraz możliwościami i organizacją przemysłu było powszechne. Porównaj przykładowo:

- L. Mumford, Technics and civilization, Routledge \& Kegan Paul Ltd, London 1934,

- S. Giedion. Mechanization takes command - a contribution to anonymous history, Oxford University Press, New York 1955.

Również Le Corbusier nie ukrywał swojego zafascynowania i inspirowania się techniką i maszynami pływającymi, jeżdżącymi i latającymi; Por. Le Corbusier, W stronę architektury, Fundacja Centrum Architektury, Warszawa 2012.

${ }^{11}$ W roku 1925 Le Corbusier zaproponował zastosowanie idei miasta współczesnego do przebudowy śródmieścia Paryża. Projekt ten pod nazwą Plan Voisin de Paris zakładał, w samym centrum miasta, niedaleko od Luwru, zastąpienie zwartej, kwartałowej zabudowy układem wolnostojących, wysokich, o potężnej kubaturze budynków.

12 Ten etap rozwoju modernizmu uważany jest też za genezę rozwoju wiedzy o człowieku w architekturze. Projektowanie małych mieszkań dla ludzi niezamożnych, poszukiwanie minimalnych wymiarów dla pomieszczeń, wyposażenia i umeblowania przyczyniło się walnie do rozeznań i do stosowania danych antropometrycznych w projektowaniu. 
${ }^{13}$ Warszawa funkcjonalna powstała w 1934 roku w wyniku połączenia działań planistycznych urbanistów pracujących w stołecznym ratuszu pod kierunkiem Jana Chmielewskiego oraz warszawskiej awangardy reprezentowanej przez Szymona Syrkusa, związanej z prowadzonymi przez Le Corbusiera Kongresami Architektury Nowoczesnej - CIAM. Razem autorzy stworzyli wizję rozwoju Warszawy w powiązaniu z regionem, jako racjonalnie zorganizowanej europejskiej metropolii, wykorzystującej położenie w dolinie Wisły i na przecięciu transkontynentalnych szlaków komunikacyjnych. Koncepcja ta, zaprezentowana wiosną 1934 roku w Londynie, wzbudziła nieukrywany entuzjazm Le Corbusiera i Waltera Gropiusa. Porównaj omówienie tego projektu w kontekście poszukiwań modelowych miasta przyszłości przez Izabellę Wisłocką [w:] Dom i miasto jutra, Arkady, Warszawa 1971.

${ }_{14}$ Przesunięcia w podstawowych grupach zatrudnienia, w trzech podstawowych sektorach gospodarki, to jest: produkcji dóbr spożywczych (rolnictwo, hodowla, sadownictwo), produkcji dóbr materialnych (przemysł i budownictwo) oraz szeroko ujmowanych usługach, było omawiane i ilustrowane już wielokrotnie; Por. przykładowo: M. Złowodzki i inni (red.), Ergonomia w warunkach gospodarki opartej na wiedzy, Komitet Ergonomii PAN, Kraków-Lublin 2012, s. 12.

${ }^{15}$ W różnych krajach proces ten różnie następował i przebiegał. We Francji sygnałem społecznym nadchodzenia nowych czasów była rewolta studencka z roku 1968, a symbolicznym wyrazem przestrzennym powstanie i rozwój podparyskiej dzielnicy biurowej - La Défense. Obecnie jest to największe skupienie funkcji biurowej w Europie, o powierzchni przekraczającej już 3,5 miliona $\mathrm{m}^{2}$.

W Wielkiej Brytanii przełomem gospodarczo-społecznym wchodzenia w okres postindustrialny i odejścia od bazowania gospodarki i energetyki na węglu było burzliwe starcie rządu premier Margaret Thatcher z górnikami i sektorem wydobywczym w roku 1984. W konsekwencji zamknięto większość kopalń, a 15 pozostawionych sprywatyzowano. Zasadniczo też ograniczono znaczenie związków zawodowych i ich wpływy polityczne. Natomiast symbolem przestrzennym przemian gospodarczych stała się likwidacja i przebudowa terenów byłych londyńskich doków. Chodziło o szeroki pas terenu opuszczony przez przedsiębiorstwa przemysłowe, usługowe, pomocnicze oraz magazynowe i składowe, długości aż 13 kilometrów, ciągnący się na wschód od samego City of London. Teren został zrewitalizowany i generalnie przebudowany w ramach szeregu niezależnych operacji urbanistycznych, z których największą, zmieniającą sylwetę miasta swoimi wysokościowcami jest Canary Wharf. Jest to wielofunkcyjny zespół o dominacji funkcji biurowej, szacowanej obecnie już na 2 miliony $\mathrm{m}^{2}$.

${ }^{16}$ Dobrym przykładem w tym względzie może być drugie co do wielkości miasto Polski Kraków. W okresie gospodarki socjalistycznej, a więc przed rokiem 1990, największym zakładem pracy był Kombinat im. Włodzimierza Lenina, zatrudniający 35 tysięcy pracowników. Obecnie największym pracodawcą w mieście jest Uniwersytet Jagielloński, w którym zatrudnione jest 7 tysięcy osób. Drugim pod względem ilości kadry zakładem pracy, nieco 
tylko mniej licznej, jest Akademia Górniczo-Hutnicza. Kraków liczy obecnie około 750 tysięcy mieszkańców, a jego aglomeracja około 1,5 miliona. Aktualnie ilość studentów w Krakowie szacuje się na ponad 160 tysięcy, z czego przeszło połowa pochodzi spoza aglomeracji. Te blisko 100 tysięcy mieszka w mieście, żywi się, bawi, korzysta z komunikacji miejskiej i dokonuje zakupów. Stanowią istotny czynnik w aktywności gospodarczej miasta, jego przedsiębiorstw i przychodach mieszkańców (tzw. pokój dla żaka).

${ }^{17}$ W zakresie obrazu pracy przewartościowania są ogromne. Przejęcie przez maszyny prac zrutynizowanych i obciążających fizycznie zasadniczo zwiększyło udział aspektów koncepcyjnych, twórczych i związanych z kierowaniem i sterowaniem procesami. Często stawia się pytanie, czy praca obecnie jest mniej męcząca, mniej wyczerpująca, niosąca mniejsze zagrożenia dla zdrowia niż w przemyśle i rolnictwie minionych epok? Odpowiedź nie jest prosta, ale wszelkie znaki wskazują, że jest to praca zdecydowanie inna, ale nie mniej obciążająca. Nie występuje już tak nagminne przeciążanie fizyczne. Prace ciężkie i bardzo ciężkie stają się rzadkością. Co więcej, pojawiły się problemy z hipokinezą, a więc niedostatkiem ruchu i monotypia czynności. Zmienia się też zasadniczo obraz wypadkowości. W okresie industrialnym wypadki były najczęstsze i najpoważniejsze w sektorze przemysłu ciężkiego i wydobywczego. Górnictwo, hutnictwo, przemysł stoczniowy i budownictwo przodowały w tym względzie. Dużo było też ich było w rolnictwie. Uważa się, że najbardziej wypadkogenne są zajęcia związane z transportem dużych mas. Obecnie odsetek ilości wypadków związanych z aktywnością zawodową jest zasadniczo mniejszy. Jak podaje Ryszard Studenski $[2010$, s. 6], obecnie w Polsce przy pracy zdarza się jedynie 1,5\% spośród wypadków śmiertelnych i zaledwie 1,4\% wszystkich wypadków. Przeważają nieszczęśliwe zdarzenia w komunikacji - w Polsce zdecydowanie dominujące, niebezpieczne stały się sporty ekstremalne i ciągle rolnictwo, co w dużej mierze wynika z jego struktury i charakteru gospodarstw rodzinnych. W okresie postindustrialnym i sytuacji gospodarki opartej na wiedzy, dominującymi zagrożeniami dla zdrowia, a w niektórych zakresach i życia są obciążenia psychiczne. Takie zjawiska jak nadmierny stres, wypalenie zawodowe, przejawy mobbingu i innych patologii w pracowniczych relacjach interpersonalnych nabierają cech wprost epidemicznych. Nadmierne obciążenia mentalne w połączeniu z aspektami pracoholizmu ma też swój znaczący udział w rozwoju szeregu chorób tzw. cywilizacyjnych.

${ }^{18}$ K. Lis, Zdrowie pracowników w rozwijajqcej się gospodarce na przykładzie Polski, [w:] Techniczne i społeczne aspekty bezpieczeństwa pracy i ergonomii, G. Dudarski, I. Gabryelewicz (red.), Oficyna Wydawnicza Uniwersytetu Zielonogórskiego, Zielona Góra 2014, s. 173-189.

19 Przyczyn wydłużania przeciętnej długości życia, wraz z postępem cywilizacyjnym, jest wiele i są one różnie tłumaczone. Poza oczywistymi, takimi jak: dostatek pożywienia, higiena osobista, zmniejszenie wypadkowości w pracy i życiu codziennym, dobre i zdrowe warunki bytowania (mieszkania), różni badacze podkreślają różne aspekty. Często wskazuje się, że decydujący obecnie jest styl życia, mający tu udział w około 50\%. Co więcej, ciekawe są dane mówiące o tym, że najdłużej żyją nie ludzie bogaci, co mogłoby się wydawać logicz- 
ne, ale osoby z wyższym wykształceniem. Tłumaczyć to można z jednej strony relatywnie wysoką stopą życiową, ale przede wszystkim kierowaniem się rozsądkiem w stylu życia. Oczywiście niezaprzeczalny jest też w krajach wysoko rozwiniętych niespotykany jak dotąd wkład medycyny, z jednej strony w ratowanie życie ludzkiego, z drugiej w profilaktykę, a więc w zapobieganie i we wczesne wykrywanie stanów chorobowych.

Prolongaty średniego czasu życia w krajach rozwiniętych, przy spadku dzietności, prowadzi do zjawiska starzenia się społeczeństw. W konsekwencji pojawia się problem konieczności wydłużenia wieku aktywności zawodowej, zgodnie z zasadą: dłużej żyjemy, a więc musimy dłużej pracować. Problem ten, będący ewidentnie tematem społeczno-gospodarczo-ekonomicznym, występuje praktycznie we wszystkich krajach Unii Europejskiej, ale w Polsce został wpleciony w nurt rywalizacji politycznej, co oczywiście nie sprzyja pragmatycznym rozwiązaniom.

${ }^{20}$ Porównaj w tym względzie książkę Davida S. Landersa o znamiennym tytule: Bogactwo i nędza narodów. Dlaczego jedni sq tak bogaci a inni tak ubodzy, WWL MUZA SA, Warszawa 2005, a także opracowanie Alvina i Heidi Tofflerów: Rewolucyjne bogactwo, 2007.

${ }^{21}$ Por. E. Tytyk, M. Butlewski, Wprowadzenie do techniki, Wydawnictwo Politechniki Poznańskiej, Poznań 2008; E. Tytyk, M. Butlewski, Ergonomia w technice, Wydawnictwo Politechniki Poznańskiej, Poznań 2011.

22 Porównaj obszerne i wieloaspektowe omówienie problematyki globalizacji z punktu widzenia socjologii, autorstwa Wilhelminy Wosińskiej, Oblicza globalizacji, Smak Słowa, Sopot 2008.

${ }^{23}$ Por. S.P. Huntington, Zderzenie cywilizacji, WWL MUZA SA, Warszawa 1998; R.B. Benjamin, Dżihad kontra mcświat, 2001; Za wymowną, acz bolesną zapowiedź napięć i konfliktów w skali globalnej, niejako symboliczny znak nowej, bezwzględnej formy zmagań, uważano zamach na World Trade Center w Nowym Jorku, dokonany w dniu 11 września 2001 roku.

24 Robert Propst, profesor w Centrum Badawczym Hermana Millera w Zeeland (Michigan), jeszcze pod koniec lat 60. XX wieku proces przemian ujął w obrazowy, poglądowy wykres, wyróżniając w nim okres powolnej, historycznej już ewolucji i okres zdecydowanego przyśpieszenia, określanego jako rewolucja (il. 4). Jako analizowane kryterium przyjęto zmiany w wielkości populacji, konsumpcji energii, postępu technologicznego, ilości pracowników biurowych, telefonów, telewizorów i komputerów. Ewolucja według Propsta zaczyna się kończyć w latach 80. wieku XIX, a rewolucja zaczęła z początkiem lat 40. wieku XX, a więc praktycznie z rozszerzeniem II wojny światowej o udział w niej USA. Oczywiście takie ujęcie ma charakter jedynie poglądowy i orientacyjny, a jego celem jest wskazanie zmian i ich tendencji. Propst tak je komentuje: „Nasi przodkowie mogli się dostosowywać do zmian które spostrzegamy obecnie jako czynnik ewolucji. Zmiany mogły być przyjmowane i adaptowane w ilościach niezauważalnych podczas życia pracownika. Dziś zmiany są rzeczywistością dominującą. Stały się nowym celem. My i nasze środowisko muszą umieć się dostosowywać do nowych wymagań" - R. Propst, Le bureau évolutif - un nouveau concept, Reboul \& Fils, Paris 1971, s. 12. 
25 Porównaj omówienie polskiego rynku biurowego na tle sytuacji i przemian gospodarczych w opracowaniu redagowanym przez Justynę Gorczycę; E-biurowce - inwestycje, architektura, produkty - polski rynek biurowy, KRN media, Kraków 2017.

${ }^{26}$ Wymownym obecnie przykładem wpływu nowych rozwiązań komunikacyjnych na proces lokowania miejsc pracy jest warszawska dzielnica Wola. Budowa drugiej linii metra dała zauważalny, dodatkowy impuls do rozwoju funkcji biurowej i przekształcania tej byłej dzielnicy przemysłowej w intensywnie rozbudowywaną dzielnicę biurowo-biznesową.

27 Pojęcie smart city jest różnie definiowane, w zależności od profilu i potrzeb definiującego. Słuszne wydaje się następujące ujęcie (Massachusetts Institute of Technology) - jest to inteligencja wynikająca z połączenia coraz bardziej skutecznych cyfrowych sieci telekomunikacyjnych, wszechobecnie występującej inteligencji komputerowego zarządzania, powszechnie występujących czujnikach i znacznikach oraz oprogramowaniu ujmującym całość struktury miejskiej. Inteligencja ta nie istnieje w oderwaniu od innych systemów miasta. Istna jest rosnąca sieć nakładających się połączeń do mechanicznych i elektrycznych systemów istniejących w budynkach, systemów wbudowanych w sprzęty gospodarstwa domowego, systemów transportu, sieci elektrycznych, sieci zaopatrzenia w wodę i usuwania ścieków oraz systemów zapewniających bezpieczeństwo mieszkańców. Uważa się, że inteligentne miasto to system składający się z czterech podstawowych zakresów:

- kreatywnej populacji realizującej działania intensywnie wykorzystujące wiedzę lub klaster takich działań,

- efektywnie działających instytucji i procedur w zakresie tworzenia wiedzy, umożliwiających jej nabywanie, adaptację i rozwój,

- rozwinięte infrastruktury szerokopasmowe, cyfrowych e-usług oraz narzędzi on-line do zarządzania wiedzą i decyzjami,

- udokumentowanej zdolności do innowacji, zarządzania i rozwiązywania problemów, które pojawiają się po raz pierwszy, ponieważ innowacyjność i zarządzanie w warunkach niepewności są kluczowe do oceny inteligencji.

Idea inteligentnego miasta jest często podejmowana zwłaszcza w relacjach planowania przestrzennego, projektowania budowlanego i wdrożeń informatycznych. Niektóre czasopisma branżowe tworzą specjalistyczne, wyodrębnione działy temu poświęcone. Por. Inteligentne Miasta - dodatek branżowy, D. Burzyńska (red.), Builder 06/2017, s. 52-67.

\section{BIBLIOGRAFIA}

Benjamin R.B., Dżihad kontra mcświat, 2001.

Inteligentne Miasta - dodatek branżowy, D. Burzyńska (red.), Builder 06/2017, s. 52-67.

Giedion S., Mechanization takes command - a contribution to anonymous history, Oxford University Press, New York 1955. 
E-biurowce - inwestycje, architektura, produkty - polski rynek biurowy 2017, J. Gorczyca (red.), KRN media, Kraków 2017.

Huntington S.P., Zderzenie cywilizacji, WWL MUZA SA, Warszawa 1998.

Landers D.S., Bogactwo i nędza narodów. Dlaczego jedni sq tak bogaci a inni tak ubodzy, WWL MUZA SA, Warszawa 2005.

Le Corbusier, W stronę architektury, Fundacja Centrum Architektury, Warszawa 2012.

Le Corbusier, Jeanneret P., Oeuvre complete 1910-1929, Les Editions d'Architecture - Edition Girsberger, Zurich 1964.

Lis K., Zdrowie pracowników w rozwijajqcej się gospodarce na przykładzie Polski, [w:] Techniczne i społeczne aspekty bezpieczeństwa pracy i ergonomii, G. Dudarski, I. Gabryelewicz (red.), Oficyna Wydawnicza Uniwersytetu Zielonogórskiego, Zielona Góra 2014, s. $173-189$.

Mumford L., Technics and civilization, Routledge \& Kegan Paul Ltd, London 1934.

Propst R., Le bureau évolutif - un nouveau concept, Reboul \& Fils, Paris 1971.

Purchla J. J.J., Jak powstał nowoczesny Kraków, Wydawnictwo Literackie, Kraków 1979.

Studenski R., Poprawianie natury, ATEST - Ochrona Pracy 3/2010, s. 4-6.

Toffler A. i H., Rewolucyjne bogactwo, 2007.

Tytyk E., Butlewski M., Wprowadzenie do techniki, Wydawnictwo Politechniki Poznańskiej, Poznań 2008.

Tytyk E., Butlewski M., Ergonomia w technice, Wydawnictwo Politechniki Poznańskiej, Poznań 2011.

Wisłocka I., Dom i miasto jutra, Arkady, Warszawa 1971.

Węcławowicz-Bilska E., Miasta i zurbanizowane struktury przestrzenne przyszłości, [w:] Ergonomia wobec wyzwań nowych technik i technologii, M. Złowodzki, T. Juliszewski, H. Ogińska, A. Taczalska (red.), Politechnika Krakowska, Kraków 2016, s. 123-138.

Wosińska W., Oblicza globalizacji, Smak Słowa, Sopot 2008.

Złowodzki M., Andrzej Robowski - filozofia architekta i dydaktyka, Czasopismo Techniczne, 2-A/1995, s. 81-100.

Złowodzki M., Ogińska H., Juliszewski T., Pawlak H., Ergonomia w warunkach gospodarki opartej na wiedzy, Komitet Ergonomii PAN, Kraków-Lublin 2012. 